\section{Units that sterilise the air you breathe}

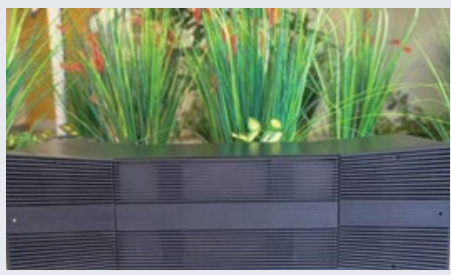

Dental Decontamination is working with Orion Eco Solutions Limited to offer Pathogen Free Air Units (PFAUs).

Dental Decontamination's PFAUs are a range of machines designed specifically to sterilise the air you breathe. This technology is recognised and used extensively in aircraft manufacture, the marine sector, and MOD.

The machine does not simply 'purify' the air, as most standard machines do. Instead, it sterilises the air to an unprecedented $\log 10$ status. It kills all airborne bacteria and destroys viruses, including the common cold, human flu, MRSA and enveloped viruses.

These systems will give both clients and employees the total peace of mind that their workplace is a safe and sterile environment.

Laboratory tests show that whereas the market leading conventional air purifier took two-and-half days to clean the air in a room, PFAUs took seven-and-half minutes. To the delight of the testing team, as well as being hugely more effective than conventional air filtration systems, the PFAU was also found to be the only one which, as well as removing unpleasant odours and particles from the air, actually destroyed air-borne bacteria and microorganisms.

PFAUs have been found to be 360 times more effective than standard air purifiers.

The PFAUs can achieve reduction in fallow time by totally changing the air a minimum of 12 times per hour.

The PFAU machines are also recognised to improve asthma, hay fever and other respiratory conditions and can even reduce snoring, alongside, removing odours such as smoke, pet, and damp.

For more information call 01253736355 or email account@ dentaldecontamination.co.uk.

\title{
Maximum comfort, optimal clarity
}

Do you use prismatic dental loupes? If so, you could benefit from the Nuview Loupe and Light Visor System, which has been developed by Nuview to provide a costeffective solution to the current increased PPE requirements.

The Nuview Loupe and Light Visor System has been designed for use with framemounted loupe/light combinations. The extended nature of the visor area - whilst complying with EN166:2001 requirements - provides sufficient space to accommodate

most types of loupes, including prismatic loupes with a front-mounted light.

With an adjustable foam-padded headband for maximum comfort, the Nuview Loupe and Light Visor System offers a superior quality visor to ensure optimal clarity.

Call Nuview to order your Starter Kit.

For more information call Nuview on 01453 872266, email info@nuview-ltd.com, or visit www.nuview.co or 'like' Nuview on Facebook.

\section{Let someone else take care of maintenance}

Now that you've returned to practice, it's time to make sure that all of your essential equipment is running smoothly.

Your air compressor is essential but don't you wish there was a way for someone else to take care of the maintenance?

DentalAir is here to help.

Starting from just $£ 9.50$ a week,

DentalAir's one-of-a-kind AirCare

Adoption Programme includes total maintenance and cover, 24-hour backup support, air quality testing services and a swift, national maintenance and repair team who will keep your air compressor in perfect working order.

Let the experts take care of your air compressor so you have time to concentrate on your patients.

For more information, contact DentalAir at info@dentalair.com or call 08009757530 .

\section{Utilising single dose dentistry}

Ketac Universal Glass Ionomer Aplicap is one of several products from $3 \mathrm{M}$ Oral Care that supports single dose dentistry for an efficient daily workflow.

It can be placed quickly and easily in just four simple steps, minimising chair time while promoting patient comfort. The application sequence is simplified by eliminating the need for cavity conditioning or protective varnish, as well as the need for etching or bonding.

\section{A trustworthy partner}

Given the challenges of modern dentistry, it's important to have a trustworthy partner you can turn to for support - especially when it comes to patient referrals.

Ten Dental+Facial is proud to be the reliable partner you can refer to with complete confidence. The friendly team is comprised of highly skilled dental professionals, including general dentists, specialist clinicians, and implantologists.
The Ketac Universal Glass Ionomer Aplicap Capsule enhances handling properties for reproducible results of single-tooth restorations, dispensing just the right amount of product to optimise efficiency and reduce wastage.

Contact 3M Oral Care to better utilise single dose dentistry in your practice.

For more information, call 08705360036 or visit www.3M.co.uk/Dental.

$3 \mathrm{M}$ and Ketac are trademarks of the $3 \mathrm{M}$ Company.

From state-of-the-art facilities based in the heart of London, they take advantage of the latest materials and equipment to deliver the best possible treatment results. In turn, you benefit from remaining integral to the referral process, before patients are returned to you for ongoing care and review.

To arrange a referral, call now.

For more information, visit www. tendental.com or call on 02033932623 . 